\title{
Detection of mutations within exons 4 to 8 of the p53 tumor suppressor gene in canine mammary glands
}

\author{
[Identificação de mutações nos exons 4 a 8 do gene p53 supressor de tumor em glândulas \\ mamárias caninas] \\ D.M.B. Souza, M.G.O. Barros, J.S.C. Silva, M.B. Silva, Z.F. Coleto, G.C. Jimenez, \\ M. Adrião, A. Wischral* \\ Universidade Federal Rural de Pernambuco - Recife, PE
}

\begin{abstract}
Fifteen female canines with mammary tumors and 6 normal females were used to study mutations in exons 4 to 8 of the p53 gene. DNA samples from the tumors, respective adjacent normal mammary tissue and mammary glands from healthy animals were sequenced and analyzed for the presence of mutations. Mutations were found in $71.8 \%$ of the samples and the most frequent were missense mutations. The most attacked exons in the mammary tumor were 5, 7 and 8, with 23.4, 31.6 and $23.4 \%$ mutations, respectively. Canine mammary tumors are related to mutations in gene p53 and mutations mostly occur in the region of the protein that is linked to the DNA in the cell nucleus, which can change the functionality of the cell and propitiate tumor growth. Despite being macroscopically normal, the mammary tissue adjacent to the tumors has mutations that can lead to recurrence if not removed together with the tumor.
\end{abstract}

Keywords: bitch, DNA, mamma, molecular biology, neoplasm, PCR

\section{RESUMO}

Para estudar as mutações nos exos 4 a 8 do gene p53, foram utilizados 15 tumores mamários, mamas normais das mesmas cadelas e seis mamas de cadelas normais. O DNA extraído das amostras de tecido foi sequenciado e analisado para a presença de mutações. Em 71,8\% das amostras obtidas foram observadas mutações, sendo as "missense" as mais frequentes. Os exons mais comprometidos foram 5, 7 e 8 com 23,4, 31,6 e 23,4\% de mutações, respectivamente. O estudo conclui que tumores mamários caninos têm relação com mutações no gene p53 e que as mutações ocorrem com maior frequência nas regiões da proteína que estão ligadas ao DNA no núcleo celular. Isto pode alterar a funcionalidade da proteína e propiciar o crescimento do tumor. As mamas adjacentes aos tumores, apesar da aparência macroscópica normal, apresentaram mutações, que podem representar recidivas se a mama não for retirada juntamente com o tumor.

Palavras-chave: cadela, DNA, mama, biologia molecular, neoplasia, PCR

\section{INTRODUCTION}

The p53 gene located in the human chromosome $17(17 \mathrm{p} 13.1)$ is a tumor suppressor gene that codifies one tetrameric phosphoprotein that acts as a transcription factor. p53 is the most frequently inactive gene in human neoplasia with functional loss commonly occurring through gene mutational events, including: nonsense, missense and splice site mutations, allelic loss, rearrangements and deletions (Hollstein et al., 1994, Levine, 1997). However, more than 90\% of missense mutations in the Tp53 reside in the sequence-specific DNA-binding domain.

The p53 mutations are found in 50-55\% of all human cancers, with the majority of alterations clustered in four of five conserved domains

Recebido em 11 de agosto de 2010

Aceito em 27 de dezembro de 2011

*Autor para correspondência (corresponding author)

E-mail: aurea@dmv.ufrpe.br 
localized between exons 5 to 8 (Van Leeuwen et al., 1996; Walker e Rapley, 1999; Muto et al., 2000; Setoguchi et al., 2001; Philibert et al., 2003; Moura-Gallo et al., 2004). In human breast cancer, Tp53 mutation is associated to more aggressive diseases and a worse prognosis for patient survival (Gasco et al., 2002).

The p53 protein contains 393 amino acids and has been divided structurally and functionally into four domains. The sequence-specific DNA-binding domain of p53 is located between amino acid residues 102 and 292. This is a protease-resistant, independently folded domain containing a $\mathrm{Zn}^{2+}$ ion that is required for its sequence-specific DNA-binding activity (Cavalcanti Junior et al., 2002). The p53 protein is a factor that enhances the transcription rate of a number of known genes that at least partially carry out p53-dependent functions in a cell (Levine, 1997). Cells lacking the p53 gene or containing mutant p53 are unable to arrest the cell cycle (Teifke and Lohr, 1996). The p53 protein plays a central role in the regulation of cell proliferation, genome stability and programmed cell death, repairing injured DNA and leading to a new transcription factor (Van Leeuwen et al., 1996; Walker e Rapley, 1999; Muto et al., 2000; Setoguchi et al., 2001). Activation of p53 often results in cell cycle arrest, presumably to allow for DNA repair before replication or mitosis. A primary mechanism by which p53 negatively controls the cell cycle is through the transcriptional activation of $\mathrm{p} 21$, which is a protein with the function of retaining the cell cycle at the $\mathrm{R}$ point, thereby allowing DNA repair. When mutations are numerous, p53 induces apoptosis and avoids the duplication of an injured cell (Albrechtsen et al., 1999).

The deduced amino acid sequence of the p53 protein in dogs is nearly $80 \%$ homologous to that of the human protein. (Chu et al., 1998). Alterations in the Tp53 gene have been identified in some canine cancer types, including colorectal tumor, thyroid carcinoma (Devilee et al. 1994), oral papilloma (Mayr et al., 1994), mammary tumor (Van Leeuwen et al., 1996; Chu et al., 1998; Klopfleisch and Gruber, 2009), osteosarcoma (Van Leeuwen et al., 1997), circumanal gland adenoma (Mayr et al., 1997) and lymphoma (Veldhoen and Milner, 1998).
Overexpression of the mutant p53 protein has also been observed in canine tumors of epithelial, mesenchymal and round cell origins (Sagartz et al., 1996, Wolf et al., 1997). The expression of p53 assessed by real-time polymerase chain reaction (PCR), however, may be heterogeneous in mammary tumors such as adenoma, adenosarcoma and their metastasis in lymphnodes (Klopfleisch and Gruber, 2009).

Mammary gland tumors are the most common neoplasms occurring in female dogs, representing $40-50 \%$ of malignant tumors (Davidson, 2003; Itoh et al. 2005; Queiroga et al., 2005). The histological tumor type is an important factor for the survival of affected animals (Sontas et al, 2009). Mammary carcinomas in dogs have similarities with breast cancer in humans, including the high prevalence of adenocarcinoma, frequency of metastasis and progressive disease (Sartin et al., 1992). Canine Tp53 is similar both in structure and function to human Tp53, therefore canine cancer may provide a useful clinical model in the search for effective anti-cancer therapies based on Tp53.

Although female canines commonly experience recurrences in other mammary tissues following the surgical excision of tumors, studies have been limited to evaluating the gene condition of the tumor tissue and few have addressed the remaining, apparently healthy tissue (Veldhoen et al., 1999). The possibility of early diagnosis from these tissues that may exhibit abnormalities expressed by genes even before the tumor develops can lead to more effective treatments prior to tumor development.

The present study was conducted with the purpose of investigating exons 4 through 8 of the Tp53 suppressor gene for frequency and mutation types in spontaneous canine mammary gland tumors and adjacent tissue without tumors, using the mammary glands of healthy female canines as the negative control.

\section{MATERIAL AND METHODS}

Fifteen canine females with malignant mammary tumors (aged between five and fifteen years) and six females without tumors submitted to elective ovary-hysterectomy (aged between 1.5 and six years, control group) of various breeds were studied. Representative sections of the mammary 
tissue (tumor, normal tissue of mammary gland adjacent to the tumor and mammary tissue from normal animals) were submitted to routine histopathological evaluation carried out by three pathologists to characterize tumor type alteration (or its absence) in affected and control mammary glands (Misdorp et al., 1999).

Genomic DNA from $0.5 \mathrm{~g}$ of mammary tissue, frozen in liquid nitrogen, was extracted using the phenol:chloroform technique. Each sample was mixed with $100 \mu \mathrm{l}$ TE (Tris $10 \mathrm{mM}$ - Invitrogen Life Technologies and $1 \mathrm{mM}$ EDTA, pH 8.0 Sigma Chemical Co.) and $100 \mu$ l phenol (Merck), $\mathrm{pH}$ 8.0. After homogenized and centrifuged at $18.000 \mathrm{~g}$, for $5 \mathrm{~min}$ at $4^{\circ} \mathrm{C}, 100 \mu \mathrm{l}$ supernatant were collected and added in $100 \mu$ l of phenolchloroform (1:1) (Maniatis et al., 1998), and centrifuged at $18.000 \mathrm{~g}$ for $5 \mathrm{~min}$. The supernatant was collected and $100 \mu$ l chloroform (Merck) was added, mixed for $1 \mathrm{~min}$ and centrifuged at $18.000 \mathrm{~g}$ for $5 \mathrm{~min}$. In a new tube, $10 \mu \mathrm{l}$ ammonium acetate 3M (Cromato Produtos Químicos LTDA) were added followed by $100 \mu \mathrm{l}$ of the supernatant of tube one and $100 \mu \mathrm{l}$ isopropanol (Merck). This mixture was homogenized for $1 \mathrm{~min}$ and incubated for $30 \mathrm{~min}$ in a freezer at $20^{\circ} \mathrm{C}$ - after that, it was centrifuged at $18.000 \mathrm{~g}$ for $15 \mathrm{~min}$. The supernatant was then removed and the pellet washed with $500 \mu \mathrm{l} 70 \%$ ethanol by centrifugation at $18.000 \mathrm{~g}$ for $5 \mathrm{~min}$ at $4^{\circ} \mathrm{C}$. Thereafter, ethanol was removed and the contents held at room temperature for $30 \mathrm{~min}$. At the end of this period, it was diluted with pure water. The extracted DNA was submitted to $1 \%$ electrophoresis agarose gel (Invitrogen Life Technologies) to determine its quality.

PCR oligonucleotides for amplification of the Tp53 fragments were designed on the basis of previously published sequencing data (Chu et al., 1998; Muto et al., 2000). Conventional PCR reactions were carried out for a final volume of $20 \mu \mathrm{l}$, containing $50 \mathrm{ng}$ of genomic DNA, $20 \mathrm{mM}$ Tris- $\mathrm{HCl}, \mathrm{pH} 8.4 ; 50 \mathrm{mM} \mathrm{KCl} ; 2 \mathrm{mM} \mathrm{MgCl}_{2}$, $0.2 \mathrm{mM}$ dNTP mix, 10 pmoles of each primer (Table 2) and 2.5 U Taq DNA-polymerase (Invitrogen Life Technologies Ltda). Each PCR amplification consisted of an initial denaturing reaction performed at $94^{\circ} \mathrm{C}$ for 2 minutes, followed by 35 cycles of denaturing at $94^{\circ} \mathrm{C}$ for $1 \mathrm{~min}$, annealing at $58^{\circ} \mathrm{C}$ for 1 minute, polymerization $72^{\circ} \mathrm{C}$ for $1 \mathrm{~min}$ and a final elongation reaction at $72^{\circ} \mathrm{C}$ for 3 minutes, performed in a thermocycler (Eppendorf Personal Mastercycler).

The PCR products were purified using the PureLink PCR Purification Kit (Invitrogen, USA) and submitted to nucleotide sequence analysis using the MegaBACE 1000 automatic sequencer with the DYEnamic ET Dye Terminator Kit (Thermo Sequenase ${ }^{\mathrm{TM}}$ II DNA Polimerase). Analyses of nucleotide sequences from PCR products, which were obtained from the sequencing analyzer, were carried out using the GenBank search program (www.ncbi.nlm.gov/BLAST).

\section{RESULTS AND DISCUSSION}

Malignant mammary tumors ranged in size from 0.8 to $22 \mathrm{~cm}$ at the largest diameter and exhibited various histological types (Table 1). The adjacent mammary gland tissue exhibited no histological abnormalities; the same was true for the animals without tumors.

Table 1. Histological type and size of malignant tumors in canine mammary glands

\begin{tabular}{ccl}
\hline Animal & $\begin{array}{c}\text { Tumor } \\
\text { size } \\
(\mathrm{cm}) *\end{array}$ & Tumor Type \\
\hline 1 & 12 & Solid Carcinoma \\
2 & 9 & Osteosarcoma \\
3 & 5 & Papillary Carcinoma \\
4 & 3.3 & Complex Carcinoma \\
5 & 2.8 & Anaplastic Carcinoma \\
6 & 15 & Anaplastic Carcinoma \\
7 & 3.5 & Complex Carcinoma \\
8 & 22 & Solid Carcinoma \\
9 & 6 & Complex Carcinoma \\
10 & 2.5 & Solid Carcinoma \\
11 & 6.5 & Squamous Cell Carcinoma \\
12 & 0.8 & Papillary Carcinoma \\
13 & 6 & Complex Carcinoma \\
14 & 7.8 & Complex Carcinoma \\
15 & 8.4 & Carcinosarcoma \\
\hline
\end{tabular}

*Tumors are measured at their largest diameter 
Table 2. Sequences of specific sense and antisense oligonucleotide primer pairs used for the amplification of exons 4 to 8 of the canine p53 gene using polymerase chain reaction (PCR)

\begin{tabular}{|c|c|c|}
\hline Exons & Primers & $\begin{array}{c}\text { Annealing } \\
\text { temperature }\left({ }^{\circ} \mathrm{C}\right) \\
\end{array}$ \\
\hline $4(\mathrm{~S} 1)$ & $\begin{array}{l}\text { 5': CTTGACTCTGGTCTCGCC } \\
\text { 3': GGGTAGGTCTTCGGGGAA }\end{array}$ & 1 \\
\hline $4(\mathrm{~S} 2)$ & $\begin{array}{l}\text { 5': CCCTATCATCCTCTGTCC } \\
\text { 3': GCCAGCCCCATGGAAACC }\end{array}$ & 58 \\
\hline $5(\mathrm{~S} 1)$ & $\begin{array}{l}\text { 5': GACCTGTCCATCTGTCCT } \\
\text { 3': ATAGATGGCCATAGCGCGG }\end{array}$ & 58 \\
\hline $5(\mathrm{~S} 2)$ & $\begin{array}{l}\text { 5':ACCCCACCCAATACCTG } \\
\text { 3': GCCTTGTCCCATCTGTAG }\end{array}$ & 58 \\
\hline 6 & $\begin{array}{l}\text { 5': TGATTCCTCCCCGATGGC/ } \\
\text { 3’: AGACCCCTCAGATGCCAA }\end{array}$ & 55 \\
\hline 7 & $\begin{array}{l}\text { 5': ACCCTGGGCCTACCTTCTA/ } \\
\text { 3’: AGGGTGGCAGGCAGGTC }\end{array}$ & 58 \\
\hline 8 & $\begin{array}{l}\text { 5': GCTTCTCTCTTCTCACCTG/ } \\
\text { 3': СТССТTCACСТCСТCTTGT }\end{array}$ & 58 \\
\hline
\end{tabular}

The amplified samples had a homology rate of $86.3 \%$ with the canine 553 protein (GenBank AAB42022.1). For the analysis of the sequences, samples of each exon from the mammary gland or the control animals were aligned in order to obtain the most conserved segment of each sequence. These segments were the reference for detecting abnormalities (mutations) in the samples from the animals with tumors, which minimized the effect of polymorphisms.

Analyses were carried out on 96 nucleotide sequences from different tissues (tumor and adjacent mammary gland tissue) and exons. A total of $71.9 \%$ of these sequences had at least one mutation in some exon. The most frequent mutations in all exons were missense mutations in both groups (Table 3 and 4). Only 27 (28.1\%) sequences had no mutation in the conserved region of each exon. The missense mutation type has been reported to have a high frequency, such as $20.0 \%$ in only three exons (5, 7 and 8) (Muto et al., 2000; Wong et al., 1999). In the present study, five exons were studied (4 to 8), allowing the observation of a greater number of mutations.

Table 3. Mutation types observed in the amplified sequences of 5 exons from the canine p53 gene in individual mammary tumors and normal glands from female canines

\begin{tabular}{|c|c|c|c|c|c|c|c|c|}
\hline \multirow{2}{*}{$\begin{array}{c}\text { Anima } \\
1\end{array}$} & \multicolumn{4}{|c|}{ Tumor tissues } & \multicolumn{4}{|c|}{ Normal Gland tissues } \\
\hline & Missense & Nonsense & Silent & Total & Missense & Nonsense & Silent & Total \\
\hline 1 & 1 & & 3 & 4 & 3 & - & 1 & 4 \\
\hline 2 & 5 & & 1 & 6 & 3 & - & 4 & 7 \\
\hline 3 & 2 & & - & 2 & 2 & 1 & 2 & 5 \\
\hline 4 & 3 & & 2 & 5 & 5 & - & 1 & 6 \\
\hline 5 & 1 & & - & 1 & 4 & - & 1 & 5 \\
\hline 6 & 5 & & 3 & 8 & 3 & - & 3 & 6 \\
\hline 7 & 7 & & 1 & 8 & 8 & 1 & 2 & 11 \\
\hline 8 & 2 & & 1 & 3 & 4 & 1 & - & 5 \\
\hline 9 & 4 & & 2 & 6 & 7 & 1 & 5 & 13 \\
\hline 10 & 3 & & 2 & 5 & 5 & 1 & 2 & 8 \\
\hline 11 & 1 & & 1 & 2 & 1 & - & - & 1 \\
\hline 12 & 2 & & - & 2 & 1 & - & - & 1 \\
\hline 13 & 3 & & 1 & 4 & 2 & 1 & 1 & 4 \\
\hline 14 & 2 & & - & 2 & - & - & - & - \\
\hline 15 & 1 & & 1 & 2 & 6 & - & - & 6 \\
\hline total & 42 & & 18 & 60 & 54 & 6 & 22 & 82 \\
\hline
\end{tabular}


Table 4. Mutation types observed in the amplified sequences of 5 exons from the canine p53 gene in mammary tissues (tumor and adjacent mammary tissue) from female canines

\begin{tabular}{|c|c|c|c|c|c|c|c|c|c|c|}
\hline \multirow{2}{*}{ Exon } & \multicolumn{5}{|c|}{ Mutations in Tumor Tissues } & \multicolumn{5}{|c|}{ Mutations in Normal Gland Tissues } \\
\hline & Missense & Nonsense & Silent & Total & $\%$ & Missense & Nonsense & Silent & Total & $\%$ \\
\hline 4 & 8 & - & 3 & 11 & 18,3 & 14 & - & 11 & 25 & 30,6 \\
\hline 5 & 9 & - & 5 & 14 & 23,4 & 14 & 3 & 4 & 21 & 25,6 \\
\hline 6 & 2 & - & - & 2 & 3,3 & 1 & - & 1 & 2 & 2,4 \\
\hline 7 & 12 & - & 7 & 19 & 31,6 & 2 & - & 3 & 5 & 6,1 \\
\hline 8 & 11 & - & 3 & 14 & 23,4 & 23 & 3 & 3 & 29 & 35,3 \\
\hline Total & 42 & - & 18 & 60 & & 54 & 6 & 22 & 82 & \\
\hline$\%$ & 70,0 & - & 30,0 & & 100,0 & 65,9 & 7,3 & 26,8 & & 100,0 \\
\hline
\end{tabular}

The occurrence of multiple mutations in $\mathrm{Tp} 53$ has previously been observed in human (Glebov et al., 1994) and canine tumors (Veldhoen et al., 1999), with a high frequency of silent mutations (Strauss, 1997). In the present study, silent mutations accounted for $30 \%$ of the mutations in the tumor tissue.

Although the high number of mutations may be considered polymorphism, it is difficult to affirm this in the present study, since these regions were more conserved in healthy females (control), which were used for comparison. One way to demonstrate that the mutations in the tumors are not polymorphisms is to compare the tumor tissue to non-tumor tissue in the same animal, where there should be no mutations (Strauss, 1997). Curiously, the normal mammary tissue adjacent to the tumors exhibited missense mutations comparable in number to the tumors studied. Moreover, despite their lower frequency, nonsense mutations were found in the normal mammary tissue of the animals bearing malignant tumors. However, these mutations were not coincident in the same animal and the notion of polymorphism can be discarded. The presence of these mutations may represent molecular alterations in the normal mammary tissue and a high risk of these mammary glands developing tumors in the future.

Mutations in the normal tissue of animals bearing tumors could indicate a germ line origin of these Tp53 abnormalities (Veldhoen et al., 1999). Unfortunately, no other tissue from these animals was available for a comparison of the observed abnormalities.

Tp53 mutations are related to a poor prognosis and shorter overall survival rates in human breast cancer (Béroud and Soussi, 1998). Indeed, 53.8\% of the animals in the present study experienced a recurrence of tumors within 1.5 years and death ensued in $71.4 \%$ of these cases.

In the mammary tumors, exons 5,7 and 8 were the most altered, with $23.4,31.6$ and $23.4 \%$ mutations, respectively (Tab. 4). Although these exons exhibited a higher degree of mutations, the results of the present study reveal a relevant mutation rate in exon $4(18.3 \%)$. In the adjacent mammary tissue, exons 4,5 and 8 were the most frequently altered (30.6, 25.6 and $35.3 \%$, respectively) (Tab. 4). The high frequency of tumor samples that harbor Tp53 mutations, compared with the results of other authors, may be due to the size of the tumors, which were large and allowed collection of tumor material without contamination from the DNA of normal tissue (Chu et al., 1998; Muto et al., 2000). The mutations in the normal mammary glands could mean that alterations may be present early in tissues, before they are detected by cytological and histopathologic exams.

Among the more frequent mutations reported here were $\mathrm{G}(17.5 \%)$ and $\mathrm{C}(13.3 \%)$ deletions and $\mathrm{A}(15.4 \%)$ and $\mathrm{T}(14.7 \%)$ insertions. When the insertion or deletion was in the third base and did not change the amino acid, the mutation was considered silent $(28.7 \%)$. If the mutation modified the reading of the codon sequence, it was considered a missense mutation. The deletion of one base can result in an altered sequence of amino acids and the production of a defected protein (Setoguchi et al., 2001). The observed rates of transversion (16.8\%) and transition $(7.7 \%)$ were lower than the $16.66 \%$ transitions observed by other authors (Lee and Kweon, 2002).

The repeated mutations in the same codon of an exon in different animals represent a hot spot, a susceptible point to gene alteration that produces 
the defected p53 protein. Mutations that exhibit more than one modification in the same codon, respective to the human $\mathrm{Tp} 53$ sequence (GenBank - AAD 28535), are considered hot- spot mutations. The most frequently altered codons in the present study are displayed in Table 5 .

Table 5. Most frequently altered codons and respective amino acid changes in tumors and normal tissue from canine mammary glands

\begin{tabular}{|c|c|c|c|}
\hline \multicolumn{2}{|r|}{ Tumor tissues } & \multicolumn{2}{|r|}{ Normal gland tissues } \\
\hline codon & Amino acid change & codon & Amino acid change \\
\hline 147 & Val $\rightarrow$ Ser or Val $\rightarrow$ Gly & 114 & Leu $\rightarrow$ Cys or Leu $\rightarrow$ Thr \\
\hline 248 & $\mathrm{Arg} \rightarrow$ Pro & 135 & $\mathrm{Cys} \rightarrow \mathrm{Leu}$ \\
\hline 266 & Gly $\rightarrow$ Val or Gly $\rightarrow$ Asp & 171 & $\mathrm{Glu} \rightarrow$ Stop or Glu $\rightarrow$ Ala \\
\hline 287 & $\mathrm{Glu} \rightarrow \mathrm{Val}$ or $\mathrm{Glu} \rightarrow$ Asn & 175 & $\mathrm{Arg} \rightarrow \mathrm{Cys}$ \\
\hline & & 266 & $\mathrm{Gly} \rightarrow$ Asp or Gly $\rightarrow$ Val \\
\hline & & 267 & $\mathrm{Arg} \rightarrow$ Leu or $\mathrm{Arg} \rightarrow$ Leu \\
\hline & & 268 & Asn $\rightarrow$ Thr \\
\hline & & 280 & $\mathrm{Arg} \rightarrow$ Glu or Arg $\rightarrow$ Stop \\
\hline & & 288 & Asn $\rightarrow$ Ile or Asn $\rightarrow$ Lys \\
\hline
\end{tabular}

A variable rate of mutations in $\mathrm{Tp} 53$ is found in mammary tumors. Some studies report no Tp53 mutations in human tumors (Kanaya et al., 2002). Others identify at least $15.0 \%$ mutations in primary mammary carcinomas (Chu et al., 1998). Other authors have also identified mutations in exons 5 and 8 , which are considered mutation hot spots (Chu et al., 1998; Muto et al., 2000). On the other hand, exon 1 has not demonstrated any mutation, based on the evidence of hot spots (Mayr et al., 2000). Exons 4 to 8 used in the present study have also been studied in canine mammary tumors by other authors. Forty-nine mutations have been identified, with $75.5 \%$ located in the central domains of canine Tp53 (Setoguchi et al., 2001).

Although few mutations were repeated in the same codon, variation was found in the codons with alterations. It has been reported that mutations may be distributed in 200 or more p53 codons (Hainaut e Hollstein, 2000). This variation in the mutation position in the gene results in different expression patterns of the p53 protein. Studies involving real-time PCR have reported a lack of homogeneity in the expression of this protein in cancerous tissue in canine mammary glands (Klopfleisch and Gruber, 2009).

Missense and nonsense mutations in mammary tumors could result in an altered 3D structure of the p53 protein. Alterations in the central domain of DNA binding of mutant human p53 have important consequences for the biological activity of the protein (spatial structure and function) (Wong et al., 1999). These mutations are especially related to codons 248 and 273, which code arginine, an amino acid responsible for the protein binding to DNA. Codon 175 (arginine) has been related to the protein conformation for this binding (Levine, 1997).

The homology between the p53 gene in humans and canines was obtained from the alignment of GenBank sequences and was $86 \%$, which is higher than previously reported rates of $81 \%$ (Chu et al., 1998) and 79.7\% (Setoguchi et al., 2001). The Tp53 sequence is composed of 828 and 883 nucleotides in canines and humans, respectively. However, only 626 nucleotides have identity between the two sequences. This difference in the sequence of these species could be due to deletions in the proline-rich regions in the canine Tp53, which developed through evolution (Kraegel et al., 1995; Veldhoen and Milner, 1998). The conserved region of the nucleotide sequences allow comparative studies on human breast cancer using the canine model. However, it was not possible to identify a single nucleotide polymorphism that repeated in all tumors and could be considered a diagnostic factor, such as the example of codon 72 for breast cancer in humans (Lång et al., 2009).

This homology allowed the analysis of codons related to the binding of DNA to the protein in canine species, including the codons responsible for the structural conformation of the protein, which were all in the central domain of DNA 
binding. Although few samples exhibited mutations in these codons, the majority of the alterations were located near them. Insertions and deletions of a nucleotide, which predominate among missense mutations, result in an incorrect reading of the sequence and defected structure and function of the peptide (Walker and Rapley, 1999; Kreuzer and Massey, 2002).

\section{CONCLUSION}

The results of the present study indicate that abnormalities in the Tp53 gene are involved in the genesis of canine mammary tumors. Moreover, these abnormalities may be present early in normal tissue, as the mutations were detected in the macroscopically and histologically normal mammary tissue adjacent to the tumors. The complete surgical excision of the total mammary chain on the affected side could be justified in order to avoid the appearance of further tumors. Knowledge on the molecular events of tumor genesis in canine species will contribute toward a better understanding of cancer in these animals.

\section{ACKNOWLEDGEMENTS}

This study was supported by grants from Conselho Nacional de Desenvolvimento Científico e Tecnológico (CNPq) - Ministério da Ciência e Tecnologia and Fundação de Amparo à Ciência e Tecnologia do Estado de Pernambuco (FACEPE) - Brazil.

\section{REFERENCES}

ALBRECHTSEN, N.; DORNREITER, I.; GROSSE, F. et al. Maintainance of genomic integrity by p53: complementary roles for activated and non-activated p53. Oncogene, v.18, p.7706-7716, 1999.

BÉROUD, C.; SOUSSI, T. P53 gene mutation: software and database. Nucleic Acids Res, v.26, p.200204, 1998.

CAVALCANTI JUNIOR, G.B.; KLUMB, C.E.; MAIA, R.C. p53 e as hemopatias malignas. Rev. Bras. Cancerol., v.48, p.419-427, 2002.

CHU, L.L.; RUTTEMAN, G.R.; KONG, J.M.C. et al. Genomic organization of the canine p53 gene and its mutation status in canine mammary neoplasia. Breast Cancer Res. Treat., v.50, p.11-25, 1998.

DAVIDSON, E.B. Treatment of mammary tumors in dogs and cats. In: NORTH AMERICAN VETERINARY CONFERENCE, Orlando. Proceedings..., 2003. pp. 1036-1038.
DEVILEE, P.; VAN LEEUWEN, I.S.; VOESTEN, A. et al. The canine p53 gene is subject to somatic mutations in thyroid carcinoma. Anticancer Res., v.14, p.2039-2046, 1994.

GASCO, M.; SHAMI, S.; CROOK, T. The p53 pathway in breast cancer. Breast Cancer Res., v.4, p.70-76, 2002.

GLEBOV, O.K.; MCKENZIE, K.E.; WHITE, C.A. $e t$ al. Frequent p53 gene mutations and novel alleles in familial breast cancer. Cancer Res., v.54, p.37033709, 1994.

HAINAUT, P.; HOLLSTEIN, M. P53 and human cancer: the first thousand mutations. Adv. Cancer Res., v.77, p.81-137, 2000.

HOLLSTEIN, M.; RICE, K.; GREENBLATT, M.S. et al. Database of p53 gene somatic mutations in human tumors and cell lines. Nucleic Acids Res., v.22, p.3551-3555, 1994

ITOH, T.; UCHIDA, K.; ISHIKAWA, K. et al. Clinicopathological surgy of 101 canine mammary gland tumors: differences between small-breed dogs and others. J. Vet. Med. Sci., v.67, p.345-347, 2005.

KANAYA, N.; OKUDA, M.; TOYAMA, N. et al. Detection of anti-p53 antibodies in dog with tumors. $J$. Vet. Med. Sci, v.64, p.973-979, 2002.

KLOPFLEISCH, R.; GRUBER, A.D. Differential expression of cell cycle regulators p21, p27 and p53 in metastasizing canine mammary adenocarcinomas versus normal mammary glands. Res. Vet. Sci., v.87, p.91-96, 2009.

KRAEGEL, S.A.; PAZZI, K.A.; MADEWELL, B.R. Sequence analysis of canine p53 in the region of exons 3 - 8. Cancer Lett., v.92, p.181-186, 1995.

KREUZER, H., MASSEY, A. Engenharia genética e biotecnologia. $2^{\mathrm{a}}$ ed. São Paulo: Brazil, Artmédica, 2002. p.272-276.

LÅNG, A.; WEGMAN, P.P.; WINGREN, S. The significance of MDM2 SNP309 and p53 Arg72Pro in young women with breast cancer. Oncol. Rep., v.22, p.575-579, 2009.

LEE, C.; KWEON, O.K. Mutation of canine tumor supresor gene p53 in a mammary gland adenocarcinoma and a malignant mast cell tumor. $J$. Vet. Clin., v.19, p.195-198, 2002.

LEVINE, A.J. p53, the cellular gatekeeper for growth and division. Cell, v.88, p.323-331, 1997.

MANIATIS, T.; FRITSCH, E.F.; SAMBROOK, J. (Eds.) Molecular Cloning: a laboratory manual. New York: Cold Spring Harbor Laboratory Press, 1998. 
MAYR, B.; SCHELLANDER, K.; SCHLEGER, W. et al. Sequence of an exon of the canine p53 genemutation in a papiloma. Br. Vet. J., v.150, p.81-84, 1994.

MAYR, B.; SCHELLANDER, K.; BOTTO, I. et al. Canine tumour suppressor gene p53-mutation in a case of adenoma of circumanal glands. Vet. Res. Commun., v.21, p.369-373, 1997.

MAYR, B.; RESCH, S.; HEPPERLE, S. et al. Comparative studies in the promoter and exon 1 regions of tumor suppressor p53 in several mammalian species: Absence of in a panel of spontaneous domestic animal tumours. J. Vet. Med. A, v.47, p.593$597,2000$.

MISDORP, W.; ELSE, R.W.; HELLMEN, E Histological classification of mammary tumors of the dog and cat. Washington: Armed Forces Institute of Pathology, 1999.

MOURA-GALLO, C.V.; SIMÃO, T.A.; RIBEIRO, F.S. et al. Mutações no gene TP53 em tumores malignos de mama: associação com fatores de risco e características clínico-patológicas, inclusive risco de óbito, em pacientes residentes no Rio de Janeiro. Rev. Bras. Epidemiol., v.7, p.167-175, 2004.

MUTO, T.; WAKUI, S.; TAKAHASHI, H. et al. p53 Gene Mutations Occurring in Spontaneous Benign and Malignant Mammary Tumors of the Dog. Vet. Pathol., v.37, p.248-253, 2000

PHILIBERT, J.C.; SYNDER, P.W.; GLICKMAN, N. et al. Influence of host factors on survival in dogs with malignant mammary gland tumors. J. Vet. Intern. Med., v.17, p.102-106, 2003.

QUEIROGA, F.L.; PÉREZ-ALENZA, M.D.; SILVAN, G. et al. Role of steroid hormones and prolactin in canine mammary cancer. J. Steroid Biochem. Mol. Biol., v.94, p.181-187, 2005.

SAGARTZ, J.E.; BODLEY, W.L.; GAMBLIN, R.M. et al. p53 tumor supressor protein overexpression in osteogenic tumors of dogs. Vet. Pathol., v.33, p.213221, 1996.

SARTIN, E.A.; BARNES, S.; KWAPIEN, R.P. et al. Estrogen and progesterone receptor status of mammary carcinomas and correlation with clinica outcome in dogs. Am. J. Vet. Res., v.53, p.2196-2200, 1992.
SETOGUCHI, A.; SAKAI, T.; OKUDA, M. et al. Aberrations of the p53 tumor suppressor gene in various tumors in dogs. Am. J. Vet. Res., v.62, p.433439, 2001

SONTAS, B.H.; OZYOGURTCU, H.; GUREL, A. et al. Evaluation of clinical and pathological characteristics of 155 canines with mammary tumours: a retrospective study. Rch. Med. Vet., v.41, p.53-59, 2009.

STRAUSS, B.S. Silent and multiple mutations in p53 and the question of the hypermutability of tumors. Carcinogenesis, v.18, p.1445-1452, 1997.

TEIFKE, J.P.; LOHR, C.V.J. P53 mutations in mammary tumor cell lines and corresponding tumor tissues in the dog. J. Comp. Path., v.114, p.205-210, 1996.

VAN LEEUWEN, I.S.; CORNELISSE, C.J.; MISDORP, W. et al. P53 gene mutations in osteosarcomas in the dog. Cancer Lett., v.111, p.173178,1997

VAN LEEUWEN, I.S.; HELLMEN, E.; CORNELISSE, C.J. et al. P53 gene mutations in osteosarcomas in the dog. Anticancer Res., v.16, p.3737-3744, 1996 .

VELDHOEN, N.; MILNER, J. Isolation of canine p53 cDNA and detailed chracterization of full length canine p53 protein. Oncogene, v.16, p.1077-1084, 1998.

VELDHOEN, N.; WATTERSON, J.; BRASH, M. et al. Identification of tumour-associated and germ line p53 mutations in canine mammary cancer. $\mathrm{Br} . J$. Cancer, v.81, p.409-415, 1999.

WALKER, M.R.; RAPLEY, R. Guia de rotas na tecnologia do gene. São Paulo: Atheneu, 1999. 334p.

WOLF , J.C.; GINN, P.E.; HOMER, B. et al. Immunohistochemical detection of p53 tumor suppressor gene protein in canine epithelial colorectal tumors. Vet. Pathol., v.34, p.394-404, 1997.

WONG, K.; DEDECKER, B.S.; FREUND, S.M.V. et al. Hot-spot mutants of p53 core domain evince characteristic local structural changes. Proc. Nat. Acad. Sci., U.S.A, v.96, p.8438-8442, 1999. 